Iosr Journal Of Pharmacy

(e)-ISSN: 2250-3013, (p)-ISSN: 2319-4219

Www.Iosrphr.Org Volume 3, Issue 3 (April 2013), Pp 59-65

\title{
Sensory Factors of Some Cassava Traditional Dishes: Foufou, Placali, Attiéké and Boiled
}

\author{
B.C. Ebah-Djedji ${ }^{1}$, D.A Sahoré2 ${ }^{2}$ B.N'Zué ${ }^{3}$ \\ ${ }^{1}$ SRT. Centre National de Recherche Agronomique, Abidjan, Côte d'Ivoire \\ ${ }^{2}$ UFR Sciences et Technologie des Aliments, Université Nangui-Abrogoua, Abidjan, Côte d'Ivoire \\ ${ }^{3}$ SRCV. Centre National de Recherche Agronomique, Abidjan, Côte d'Ivoire
}

\begin{abstract}
Ivorian traditional dishes, Placali, Attiéké, Foufou and Boiled cassava were prepared from improved cassava varieties CM (52), I88/00158, IM84 and TMS4 (2) 1425 and control variety Bonoua 2 in "Centre National de Recherche Agronomique, Abidjan, Côte d'Ivoire". The sensory factors (color, smell, taste, degree of cooking) of these five cassava varieties are determined. And it appeared that the different cassava varieties studied were suitable for the preparation of these dishes
\end{abstract}

Keywords: Attiéké, Boiled, Cassava, Foufou, Placali, Roots, Sensory factors, Traditional dishes

\section{INTRODUCTION}

Edible roots and tubers, yam, taro, sweet potato cassava, etc, were the main foodstuffs of the tropical and subtropical zones populations [1], [2], [3]; Among these food crops, cassava (Manihot esculenta Crantz) was the most important foodstuff in these regions by its production and its consumption. World cassava production was estimated at 224 million tons in 2007 of which 114 million tons coming from Africa were 52\% of production [4] In Côte d'Ivoire; cassava was both subsistence farming and cash crops. Its derived products were multiple and subject to national and sub-regional trade [1]. On the level of the food crops production, the cassava occupied the second rank in front of plantain with 1,400,000 tons/year). Most of this production was in the south of the country [5]; Cassava toxicity, due to its content of hydrocyanic acid is well known and several traditional methods existed to reduce the concentration of this antinutritional factor. These methods included soaking, cooking, drying, roasting and fermentation retting. The interest of the cassava was its adaptation to the harsh climate and poor soils, providing a wide range of tolerance in the growing season, and the harvest period. Cassava roots were thus available when needed [6]. Processing technologies related to this culture were easy and controlled by most populations. What allowed the development of several types of traditional products among others "Attiéké" [7], [8], "Foufou" and the "Placali" [9], So what would cassava varieties developed by the CNRA culinary properties which presented interesting? It was this interrogation that we tried to answer in this work. Specifically it will be to determine the aptitude for the processing of the tuberous roots of some cassava varieties developed in this research institution.

\section{2-1. Material vegetable}

\section{MATERIALS AND METHODS}

Cassava (Manihot esculenta Crantz) varieties roots studied came from the collection of the «Centre National de Recherche Agronomique" (CNRA). These were the improved crop varieties CM (52), I88/00158, IM84, TMS4 (2) 1425 and control variety Bonoua 2. These cassava roots were harvested at different stages of the growth cycle $(11,13,15$ and 17 months after planting) in the experimental plots of the CNRA to Adiopodoumé $17 \mathrm{~km}$ of Abidjan. They were then transported the same day of harvest to Abidjan in jute [10] for the biochemical and technology analysis. Harvests were carried out during the years 2006, 2007 and 2008. Sensory factors (color, smell, taste, degree of cooking) of four traditional dishes: Foufou, Placali, Attiéké and Boiled cassava prepared with these five cassava varieties were studied to determine the aptitude for the processing of these cassava roots

\subsection{Foufou}

Cassava tuberous roots are peeled, cut into small pieces and washed with water. These pieces are cooked in boiling water until they soften and they are crushed, still warm, in small wooden mortar. This may take 15 to 45 min depending on the texture (more or less smooth) desired dough. Balls are rolled manually from the dough and served with sauces. These pastes are called cassava "Foufou" [11]

\section{3 .Placali}

Cassava tuberous roots are peeled, crushed and mixed with a small amount of cassava fermented before. The paste thus obtained is again to ferment for one to two days. The fermented dough is transformed into a gel called "Placali" after simmering [9] 


\subsection{Attiéké}

Cassava tuberous roots are peeled, crushed and mixed with a small amount of cassava fermented before. The paste thus obtained is again to ferment for one to two days. At the end of fermentation time which has eliminated much of the hydrocyanic acid that naturally contained cassava, pulp is dehydrated, filtered, dried and winnowed, and then update steam. After a few minutes of cooking, the product was ready to be consumed "Attiéké" [12]

\subsection{Boiled}

Roots of sweet cassava are peeled, cut into chunks and then washed with water. These pieces are cooked in boiling salted water and consumed immediately in the form of boiled cassava or salad, mixed vegetables and seasoned with oil or sauce [13]

\subsection{Cooking test}

$30 \mathrm{~g}$ pieces of cassava tuberous roots were weighed and cooked in $500 \mathrm{ml}$ of water boiling for $20 \mathrm{~min}$ in an aluminum cylinder of $100 \mathrm{ml}$, covered with a watch glass. After cooking, it was collected on a sieve $(1 \mu \mathrm{m}$ mesh). These pieces of roots of cassava were cooled and washed after 10 immersed in cold water collected in a pan more flared. The mixture is left to stand for $2 \mathrm{~min}$. To suck the last drops of water, a shot past tissue was slightly below the sieve and cooked cassava pieces are weighed into petri dishes dried, known masses. The petri dishes are then brought to the oven for $15 \mathrm{~h}$ at $70^{\circ} \mathrm{C}$ and then at $103{ }^{\circ} \mathrm{C}$ for $3 \mathrm{~h}$. Out of the oven, the petri dishes were cooled and weighed again and then the amount of water absorbed and the leached solids were determined by mass differences. [10]

\subsection{Sensory analysis}

The sensory analysis was performed according to the method described by Dadzie and Orchard [14] .The objective was to obtain descriptive data quantified of all our samples.

\subsection{Statistical Analysis}

The statistical analyzes were performed using Statistica 7.0 software (Stat Soft Inc., Tulsa, USA Headquarters) and XLSTAT-Pro 7.5.2 (Addinsoft Sarl, Paris, France). The homogeneity of the parameters studied was determined by comparison of the means by Duncan's test at $5 \%$

\section{3-1- Foufou}

\section{RESULTS}

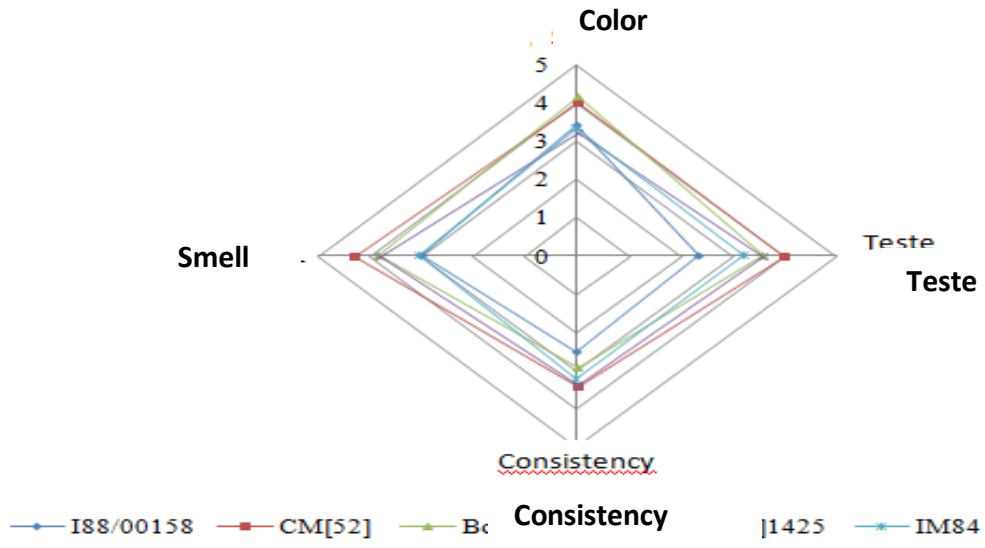

Fig 1: Sensory factors of five cassava varieties roots Foufou

The five cassava varieties roots Foufou color presented the appreciation notes which ranged between $3.22 \pm 0.80$ and $4.18 \pm 0.70$ (Fig 1). Thus, they were $4.18 \pm 0,70 ; 3,40 \pm 0,40 ; 3,32 \pm 0,40 ; 3,22 \pm 0.80$ and 4.00 \pm 0.50 respectively for the improved cassava varieties CM (52), I88/00158, IM84 and TMS 4 (2) 1425 and control variety Bonoua 2.There appeared no significant difference at $5 \%$ between the appreciation notes of Foufou color. Regarding the smell of Foufou made from the 5 varieties of cassava, appreciation notes were between $4.31 \pm 0.60$ and $3.00 \pm 0.40$ (Fig 1). Highest smell appreciation note is obtained with the improved variety of cassava CM (52) (4.31) and the lowest is owned by the cassava variety I88/00158 (3.00). 
The Foufou of cassava varieties Bonoua TMS4 2 (2) 1425 had appreciation notes smell intermediaries. It appeared only differences significant at 5\% between the appreciation notes of cassava varieties I88/000158 and IM84 Foufou smell and those of cassava variety CM (52). The panel tasters appreciation notes allotted to Foufou oscillate between $4.00 \pm 0.40$ and $2.35 \pm 0.50$ (Fig 1). The highest appreciation note is given with the cassava variety CM (52) Foufou (4.00) and the least low is obtained by the cassava variety I88/00158 (2.35). The values obtained did not differ significantly from a variety with another, except for the difference observed between those of varieties I88/00158 and IM84. The consistency of Foufou of the five cassava varieties recorded appreciation notes ranged between $2.50 \pm 0.50$ and $3.41 \pm 0.40$ (Fig.1). The lowest appreciation note of Foufou consistency is obtained with cassava variety I88/00158 (2.5) and the highest is owned by the cassava variety CM (52) (3.41). The analysis of averages comparison showed that the Foufou consistency values did not vary significantly from one variety to another, except for the difference revealed between the consistency values of varieties I88/00158, Bonoua 2 and that of the variety CM (52). Varieties Bonoua 2, TMS 4 (2) 1425 and IM84 had the intermediate values

\section{3-2-Placali}

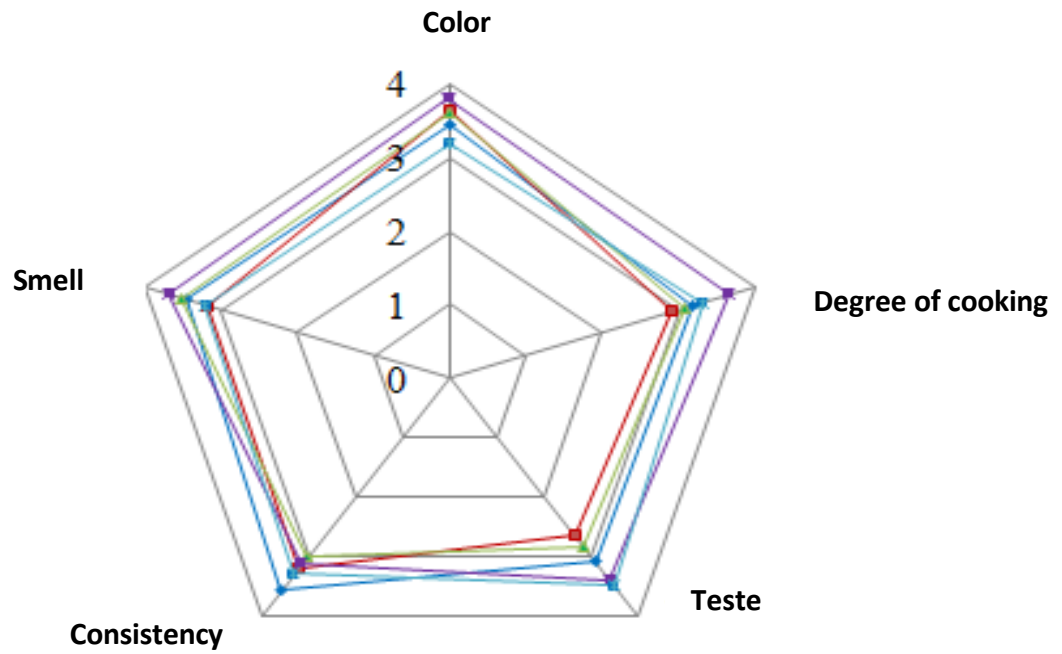

$\longrightarrow$ I88/00158 $\multimap \mathrm{CM}[52] \multimap$ Bonoua $2 \longrightarrow$ TMS4[2]1425 $\rightarrow$ IM84

Fig 2: Sensory factors of five cassava varieties roots Placali

The color of Placali made with the improved cassava varieties TMS 4 (2) 1425, I88/00158, CM (52), IM84 and Bonoua 2 had the appreciation notes which ranged from $3.19 \pm 0.42$ to $3.81 \pm 0.96$ (Fig 2). These extreme values are obtained respectively with varieties IM84 and TMS 4 (2) 1425. There was no significant difference at $5 \%$ between the different values of color appreciations.

Regarding the smell of five cassava varieties Placali, the appreciation notes ranged from $3.18 \pm 0.87$ to $3.66 \pm 0.46$ (Fig 2). These extreme values are obtained respectively with the varieties CM (52) and TMS2 (4) 1425. Statistical tests showed that there were no significant differences at $5 \%$ between the Placali smell appreciations values of different cassava varieties studied. The degree of cooking improved cassava varieties Placali and that of the control variety Bonoua had two appreciation notes which ranged from $2.90 \pm 1.14$ to 3.66 \pm 0.62 (Fig 2). There is no difference significant at the $5 \%$ level between the different values obtained.

Placali taste of different cassava varieties had appreciation notes ranging from $2.63 \pm 1.12$ (CM (52)) to $3.50 \pm 0.37$ (IM84) (Fig 2). These values do not differ significantly at the 5\% one variety to another. Improved cassava varieties of I88/00158, TMS4 (2) 1425 and control variety Bonoua 2 had intermediate appreciations notes with respective values of $2.83 \pm 0.56,3.41 \pm 0.66$ and 3, $09 \pm 0.94$. Consistency of improved cassava varieties Placali I88/00158, TMS4 (2) 1425, CM (52), IM84 and control variety Bonoua 2 recorded respective appreciation notes of $3,58 \pm 0,59,3.13 \pm 0,63,3,21 \pm 0,52,3,31 \pm 0.81$ and of $2.83 \pm 0.28$ (Fig 2). Statistical analyzes showed that these values are not significantly different at the $5 \%$ level between them. 


\section{3-3-Attiéké}

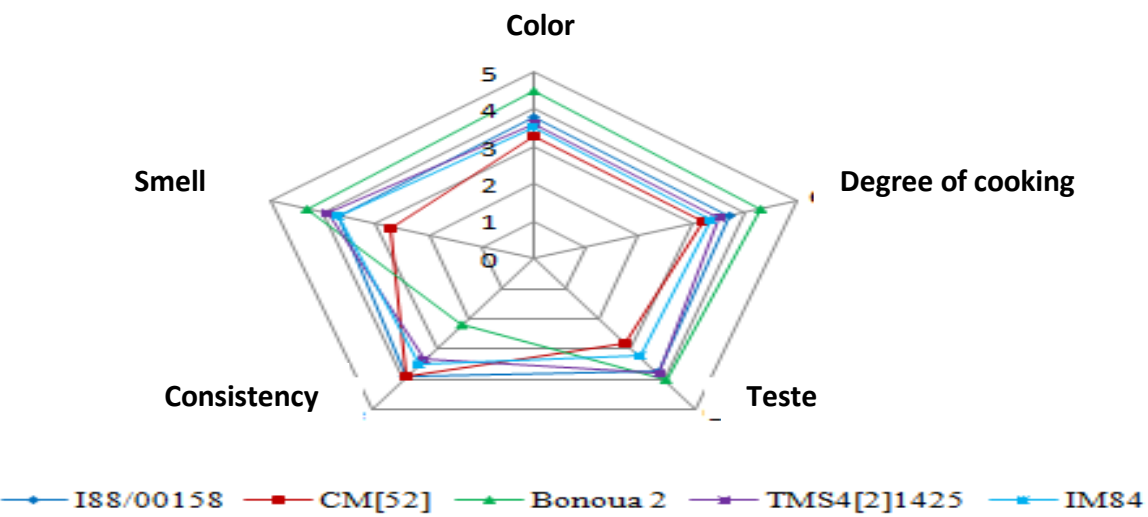

Fig 3: Sensory factors of five cassava varieties roots Attiéké

the color of control variety Bonoua 2 and improved cassava varieties Attiéké had the appreciation notes which ranged from $3.30 \pm 1.42$ (CM (52)) to $4.53 \pm 0.69$ (Bonoua 2) (Fig 3). These values did not differ significantly at the 5\% from one variety to another The Attiéké of cassava varieties CM (52), I88/00158, IM84, TMS 4 (2) 1425 and control variety Bonoua 2 had respective appreciation notes of $3.30 \pm 1,42,3,80 \pm 0,92,3,54 \pm 0,44,3,63$ \pm 0.58 and $4.53 \pm 0.69$. Regarding the taste of Attiéké made from five cassava varieties, appreciation notes were between $2.80 \pm 1.14$ (CM (52)) and $4.05 \pm 0.11$ (Bonoua 2) (Fig 3). These values do not differ significantly at the $5 \%$ one variety to another.

Improved cassava varieties I88/00158 TMS4 (2) 1425, CM (52), IM84 and control variety Bonoua 2cassava witness Attiéké degree of cooking recorded respective appreciation notes of $3.70 \pm 0,82,3,51 \pm$ $0,80,3,20 \pm 1,14,3,33 \pm 0.51$ and $4.30 \pm 0.92$ (Fig 3). These values did not differ significantly at the $5 \%$ from one variety to another. Regarding the smell of Attiéké made from five cassava varieties, appreciation notes ranged from $2.70 \pm 1.06$ to $4.30 \pm 0.71$ (Fig 3). These values do not differ significantly at the $5 \%$, except for the differences observed between varieties CM52 and Bonoua 2. The highest appreciation note of Attiéké smell was obtained with the improved variety of cassava Bonoua 2 and the lowest is owned by the cassava variety CM (52). The cassava varieties I88/00158, TMS4 (2) 1425, CM (52), IM84 and the control variety Bonoua 2 Attiéké consistency recorded appreciation notes ranged from $2.21 \pm 0.21$ (Bonoua 2) to $3.95 \pm 0.25$ (I88/00158) (Fig 3). It appeared significant differences at $5 \%$ between these values, except for the difference revealed between the cassava varieties CM (52) and I88/00158

\section{3-4-Boiled cassava}

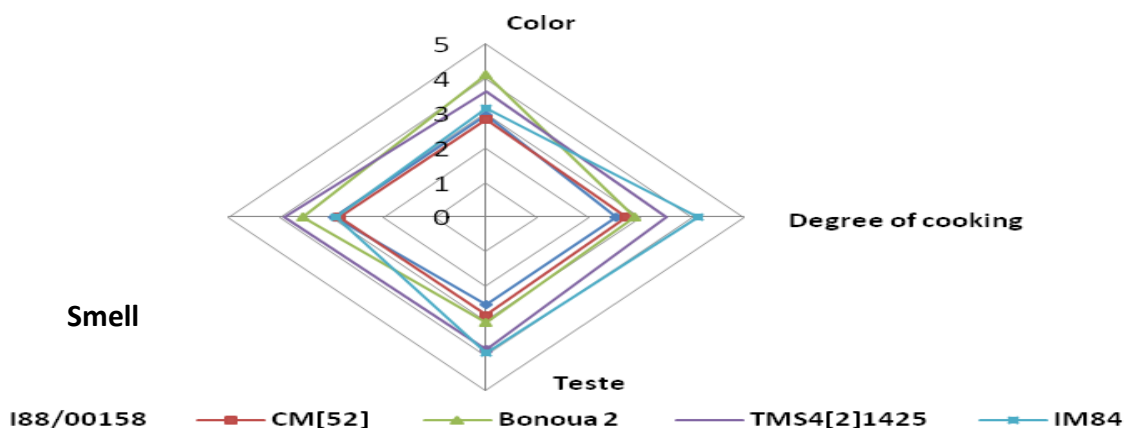

Fig 4: Sensory factors of five cassava varieties roots boiled cassava

The color of Cassava varieties TMS4 (2) 1425, I88/00158, CM (52), IM84 and Bonoua 2 Boiled had appreciation notes which are respectively $3.63 \pm 0.70,2,96 \pm 0.56,2.81 \pm 0.36,3.13 \pm 0.52$ and $4.11 \pm 0.45$ (Fig 4). These values did not differ significantly at 5\%, except for the difference existing between the values of cassava varieties CM (52), I88/00158 and that the control variety Bonoua 2. Regarding the cooking degree of the cassava Boiled the appreciation notes ranged from $2.53 \pm 0.70$ to $4.13 \pm 0.61$ (Fig 4). The appreciation note of the highest cooking is detained by the improved cassava variety IM84 (4.13) and the lowest is obtained with cassava variety I88/00158 (2.53). It appeared significant differences at $5 \%$ only between the cooking appreciation notes of the cassava varieties I88/00158, CM (52), Bonoua 2 and that of variety IM84. 
Regarding improved cassava varieties and variety Bonoua 2 Boiled taste appreciation notes ranged from $2.56 \pm 0.69$ (I88/00158) to $3.83 \pm 0.66$ (TMS 4(2) 1425) (Fig 4). These appreciation notes did not differ significantly at $5 \%$ from a variety with another, except for varieties I88/00158 and IM84. The cassava varieties I88/00158, TMS 4 (2) 1425, CM (52), IM84 and control variety Bonoua 2 Boiled smell recorded appreciation notes which ranged from $2.84 \pm 0.41$ (CM (52)) to $3.91 \pm 0.24$ (TMS 4 (2) 1425) (Fig 4). The statistical analysis showed that the Boiled smell appreciation notes of the cassava varieties CM52, IM84 and I88/00158 differ significantly at 5\% from that variety TMS 4 (2) 1425.

\section{DISCUSSION}

Sensory factors of the local dishes, Boiled, Attiéké, Foufou and Placali, prepared with improved cassava varieties TMS 4 (2) 1425, IM84, I88/00158, CM (52) and control variety Bonoua 2 related to color, consistency, smell, taste and cooking were studied. Indeed, the variance analysis showed that these sensory properties differ from the same technological application from one variety to another. The cassava varieties Attiéké color did not differ significantly from a variety to another at 5\% according to the test of Duncan (Fig 3). That highlighted the homogeneity of the food color. This observation suggested that the color did not appear to be a determining factor in the preference for different qualities of Attiéké.

Moreover, Pokou [15] showed that Attiéké usually arrived on the market had an acceptable color and that consumers were indifferent between yellow and white colors of the product However, according to Aboua, et al. [16], the evaluation of the Attiéké quality would often be done by the appreciation of its color. Changes of smell appeared at the Attiéké of cassava varieties CM (52) and Bonoua 2. Except the smell of the variety CM (52) which is not pleasant, the smell of the Attiéké of varieties TMS4 (2) 1425, I88/00158, IM84 and variety Bonoua 2 did not differ from one variety to another (Fig 3) Thus they had all Attiéké pleasant smells. At the cassava varieties Attiéké taste, no significant difference was revealed. This suggested that the taste of cassava varieties Attiéké was similar (Fig 3). Then gave these all varieties tasteful Attiéké. With the exception of the variety CM (52) with a very pleasant smell Attiéké, Varieties TMS4 (2) 1425, I88/00158, IM84 and control variety Bonoua 2 can be recommended for making the Attiéké because according [15] , taste and smell appeared as main features of Attiéké. According to this author Attiéké consumers preferred a soft, clean, with a pleasant smell. The Attiéké of different cassava varieties did not differ by the sensory property "degree of cooking" according to the test mean comparison by Duncan at $5 \%$. This result resulted in a cooking of cassava varieties similar to one variety to another. (Fig 3)

Moreover, the consistency of the cassava varieties Attiéké did not differ from one variety to another (Fig 3), with the exception of the difference between the varieties CM52 and I88/00158. In order of preference based on sensory factors, the Attiéké Bonoua 2 would be the most appropriate, followed by those of I88/00158, TMS4 (2) 1425, IM84 and CM (52). The cassava varieties CM52 and I88/00158 and that of variety Bonoua 2 was different Boiled color (Fig. 4). That derived from appreciation notes of this sensory property which varied significantly at $5 \%$. Control variety Bonoua 2 with the highest color appreciation note presented Boiled of attractive coloring (Fig. 4). Moreover, cassava varieties CM (52), Bonoua 2 and I88/00158 Boiled degree of cooking were similar by the nonexistence significant differences between the appreciation notes of these varieties "degree of cooking". These varieties are distinguished from the variety IM84 by their high degree of cooking. So they were cooked better roots. (Fig. 4). This could be explained by a better softening of the roots during cooking according to, Raffaillac and Akakpo [17]. Also during this hydrothermal treatment, duration and pressure used affect the starch content tuberous roots, [18] (Ayenor, 1974). This processing changed the physicochemical structures of the final product and promoted partially enzymatic hydrolysis by starch dispersion [10]. It also improved the organoleptic qualities, destroyed pathogenic agents (Bell and Favier, [19] 1982). Indeed, during a cooking in water, the tuberous roots lost some nutrients including amino acids by solubilization in the water. The mineral content also decreased by dissolution as soluble vitamins (Bell and Favier [19], 1982; Trèche, 1989) [20],

The cassava varieties Boiled did not differ in their taste except for the taste difference observed between varieties I88/00158 and IM84. (Fig. 4). Variety I88/00158 with an appreciation note taste weaker, had the taste of Boiled least appreciated by the tasters. (Fig. 4) The smell of the Boiled cassava varieties did not differ from one variety to another, except the distinction of the smell of boiled varieties CM (52), I88/00158 and IM84 and that of variety TMS4 (2) 1425 . The smell of cassava varieties Boiled was generally pleasant. Variety TMS4 (2) 1425 gave the smell of boiled seen the most pleasant tasting panel of observation (Fig. 4). By order of preference according to sensory factors, Boiled of cassava variety TMS4 (2) 1425 was the most appropriate followed by those of IM84, Bonoua 2, CM (52) and I88/00158 (Fig.4). 
For the Foufou of cassava varieties (Fig 1), the notes given by the sensory factor Color tasters did not differ significantly at $5 \%$. This reflected homogeneity of cassava varieties Foufou color. The smell of cassava varieties Foufou did not vary significantly from one variety to another (Fig 1)., with the exception of the difference between the smell of the I88/00158 and IM84 varieties and the variety CM (52) (Fig. 1). This suggests that cassava varieties had all the good smells. The cassava variety CM (52) had the Foufou smell the more enjoyable by its highest appreciation value (Fig 1)At the cassava varieties Foufou taste, no significant difference was revealed (Fig 1), except for varieties I88/00158 and IM84. This suggests that taste of the cassava varieties Foufou was similar (Fig 1). Then, these cassava varieties were all interesting Foufou tastiest. Moreover, cassava variety CM (52) Foufou was best appreciated, followed by those of cassava varieties Bonoua 2, TMS4 (2) 1425, IM84 and I88/00158. (Fig 1)The Intermediate values of the cassava varieties Bonoua 2, TMS4 (2) 1425 and IM84 Foufou consistency reflected by the taste average quality held by these varieties. This cassava varieties Foufou consistency did not distinguish from that of cassava varieties I88/00158 and CM (52). In terms preference of consistency, cassava variety CM (52) Foufou with the highest consistency appreciation note was the best indicated, (Fig 1) followed by those of cassava varieties Bonoua 2, TMS4 (2) 1425, IM84 and I88/00158.Slight variations are not significant at the 5\% appeared during the cassava varieties CM (52), Bonoua 2, TMS4 (2) 1425, IM84 and I88/00158 Placali tasting concerning sensory factors color, odor, cooking taste and consistency. (Fig 2). Also, the rank order of preference varieties for the preparation of the Placali was as follows: TMS4 (2) 1425, I88/00158, IM84, Bonoua 2 and CM (52). (Fig 2)

\section{CONCLUSION}

Sensory factors Analysis of the traditional dishes, Attiéké, Boiled, Foufou and Placali, everyone made from improved cassava varieties "TMS4 (2)1425", "IM84", "I88/00158" and CM (52 and control variety Bonoua 2 has highlighted the most indicated for these technological applications Thus we classified these varieties in the order preferably according to the dishes as follow

1) Attiéké: Bonoua 2, I88/00158, TMS4(2)1425, IM84 et CM(52);

2) Boiled: TMS4(2)1425, IM84, Bonoua 2, CM(52) et I88/00158;

3) Foufou: CM(52), Bonoua 2, TMS4(2)1425", IM84 et I88/00158;

4) Placali: TMS4 (2)1425, I88/00158, IM84, Bonoua 2 et CM52.

\section{REFERENCES}

[1] FAO. Guide d'exportation pour les Plantes à Racines et Tubercules en Afrique de l'ouest et du centre. Centre Technique de Coopération Agricole et Rurale (CTA), Février 2010, 32

[2] N. G Amani.et A. Kamenan. Potentialités nutritionnelles et technologie traditionnelle de transformation Des Denrées Amylacées en Cote d'Ivoire. 2e Atelier International. Voies Alimentaires d'Amélioration des Situations Nutritionnelles en Afrique de l'Ouest : les rôles des technologies alimentaires et nutritionnistes. Ouagadougou, Burkina Faso, 2003

[3] D.A, Sahoré, G. J Nemlin. Effect of Technological Treatments on Cassava (Manihot Esculenta Crantz) Composition, Food and Nutrition Sciences, 1 (1), 2010, 19-23

[4] FAO. Développement des systèmes agricoles: concepts, méthodes, application, Rome -Italy. 1989

[5] H. Ducroquet L'agriculture ivoirienne à la loupe (I). Le professionnel agricole (3), 2002, 10-12

[6] S. Trèche. Importance du manioc en alimentation humaine dans différentes régions du monde. In : Transformation Alimentaire du manioc, Aglor E, Brauman A, Griffon D, Trèche S (éditeurs), Orstom, Paris, 1995, 234-243

[7] N. A., Kouadio, K. Mosso. K. Kouakou, S. F Agbo. Etude Comparative des Méthodes Traditionnelles de la Préparation de l'Attiéké dans le sud de la Côte d'Ivoire. Cahiers de la recherche scientifique et technique. 108, 1991, 703-706.

[8] D.A, Sahoré, G. J Nemlin Changes in biochemical properties of fresh Attiéké during its storage, Food and Public Heath, 2(4), 2012, 99-103

[9] V Zouménou. Etudes physico-chimiques et nutritionnelles de quelques préparations alimentaires à base de manioc (Manihot esculenta Crantz). Thèse de Doctorat 3è cycle ès Sciences naturelles (Option: Biochimie- Nutrition) Université de Cocody Abidjan, 1994.

[10] N.G Amani, F, Aboua, K. Kouadio, A Kamenan. Influence of hydrothermal Treatments on the Physico- Chemical Properties of Cocoyam flour. Application to Processing of the "Futu" type instant flours Sciences des aliments. 17 (1), 1997, 35-44.

[11] K. Mosso, N. Kouadio, G. J. Nemlin. Transformation traditionnelle de la banane, du manioc, du Taro et de l'igname dans les régions du centre et du sud de la Côte d'Ivoire. Industries Alimentaires et Agricoles. 1996, 91-96.

[12] F. Aboua. Simple Methods for Evaluating Attiéké Spoilage in Food Chemistry, Trop. Sci, 3(1), 1989, 313-317.

[13] J.C. Favier, S. Cheyassus-Agnès et G. Gallon. La technologie traditionnelle du manioc au Cameroun. Influence sur la valeur nutritive. Annales de la Nutrition et de l'alimentation. 25, 1971, 1-59.

[14] B. K. Dadzie et J. E. Orchard. Évaluation post-récolte des hybrides de bananiers et bananiers plantain: Critères et méthodes. Guides techniques INIBAP 2. Institut international des ressources phylogénétiques, Rome, Italie ; Réseau international pour l'amélioration de la banane et de la banane plantain, Montpellier, France; Centre technique de coopération agricole et rurale (ACP-UE), Wageningen, Pays-Bas, 1997, 77

[15] K. Pokou. Analyse économétrique de la demande des traits caractéristiques des produits de Manioc en Milieux Urbains de Côte d'Ivoire : cas de l'Attiéké. Centre Ivoirien de Recherches Economiques et Sociales (CIRES). Université d'Abidjan-Cocody. 2006,32

[16] F .Aboua, K Konan., A. Kossa et A. Kamenan. Evolution des teneurs d'acide cyanhydrique et d'Acide Oxalique au cours de la transformation du manioc en "Attiéké". Agronomie africaine, 1 (2), 1989, 117-122

[17] J. P. Raffaillac et K. E. Akakpo. Matière sèche des racines de manioc et aptitude à la transformation en Foufou au Togo. Cahiers Agricultures. 5, 1996, 185-188. 
[18] G. S. Ayenor. Particulate Properties and Rheology of Pregelled Yam (Dioscorea rotundata) Product, Journal of Food Science. 41, 1974, 180-182.

[19] A. Bell, J.C. Favier. Influence des Transformations Technologiques Traditionnelles sur la Valeur Nutritive de l'igname (Dioscorea spp) au Cameroun. Revue Science et Technique (Sciences Santé). (2), 1982, 135-150.

[20] S. Trèche. Potentialités nutritionnelles des ignames (Dioscorea spp.) cultivées au Cameroun. Vol. I : Texte. Vol. II : annexes. Thèse, Editions de l'ORSTOM, Collection Etudes et Thèses, Paris, 1989. 595 